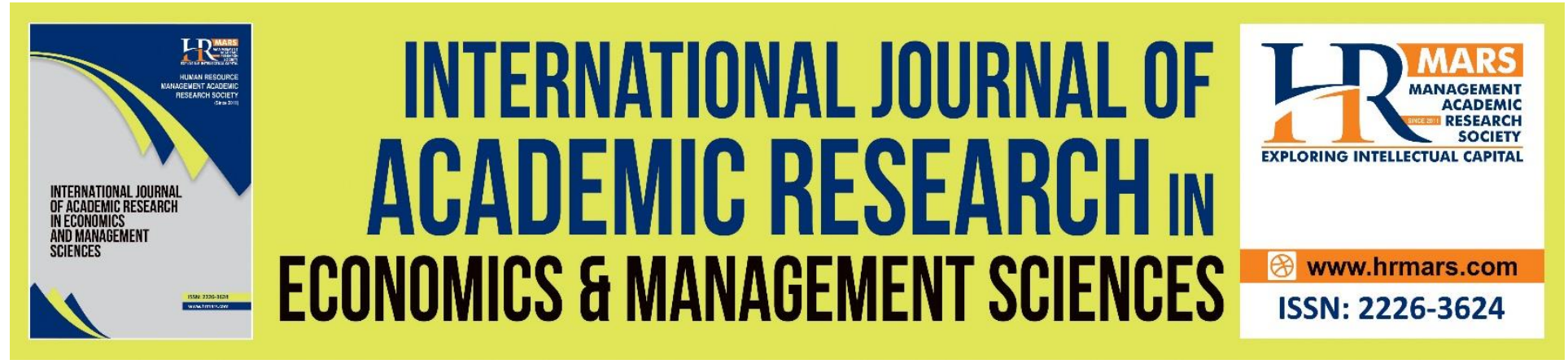

\title{
Is There A Need for An Improved Religiosity Measurement Tailored to Consumer Research?
}

Johari Bin Abdullah, Firdaus Abdullah and Saimi Bin Bujang

To Link this Article: http://dx.doi.org/10.6007/IJAREMS/v10-i1/9550

DOI:10.6007/IJAREMS/v10-i1/9550

Received: 20 January 2021, Revised: 19 February 2021, Accepted: 29 February 2021

Published Online: 20 March 2021

In-Text Citation: (Abdullah et al., 2021)

To Cite this Article: Abdullah, J. Bin, Abdullah, F., \& Bujang, S. Bin. (2021). Is There A Need for An Improved Religiosity Measurement Tailored to Consumer Research? International Journal of Academic Research in Economics and Managment and Sciences, 10(1), 92-107.

Copyright: (C) 2021 The Author(s)

Published by Human Resource Management Academic Research Society (www.hrmars.com)

This article is published under the Creative Commons Attribution (CC BY 4.0) license. Anyone may reproduce, distribute, translate and create derivative works of this article (for both commercial and non-commercial purposes), subject to full attribution to the original publication and authors. The full terms of this license may be seen at: http://creativecommons.org/licences/by/4.0/legalcode

Vol. 10, No. 1, 2021, Pg. 92 - 107

http://hrmars.com/index.php/pages/detail/IJAREMS

JOURNAL HOMEPAGE

Full Terms \& Conditions of access and use can be found at http://hrmars.com/index.php/pages/detail/publication-ethics 


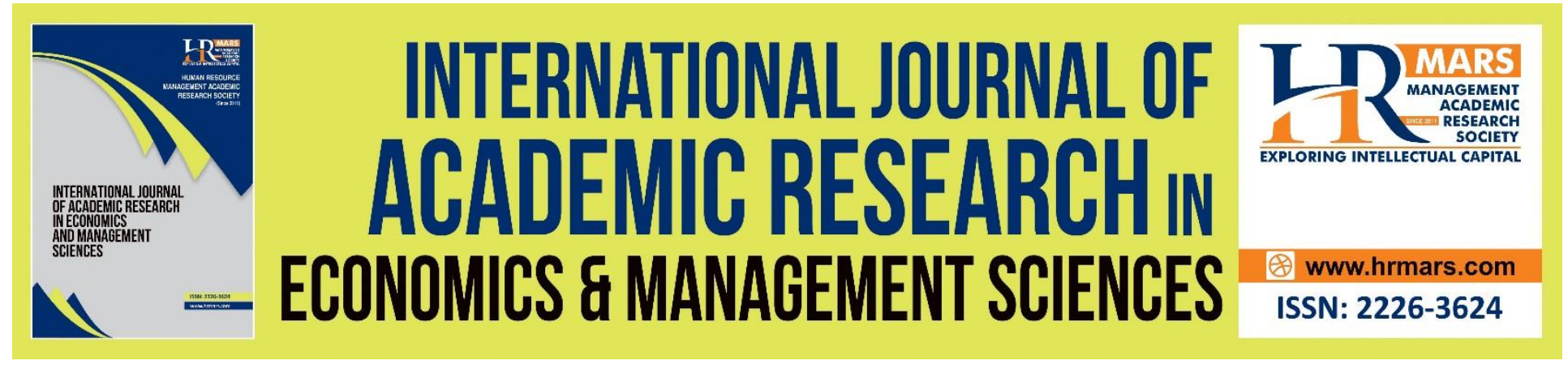

\title{
Is There A Need for An Improved Religiosity Measurement Tailored to Consumer Research?
}

\author{
Johari Bin Abdullah \\ Universiti Teknologi MARA, UiTM Sarawak Branch, Mukah Campus, Malaysia \\ Email: johariabdullah@uitm.edu.my
}

\author{
Firdaus Abdullah and Saimi Bin Bujang \\ Universiti Teknologi MARA, UiTM Sarawak Branch, Samarahan Campus, Malaysia
}

\begin{abstract}
Religiosity has been part of the cultural subsystem, which consists of beliefs, norms, and value systems that influence human behaviour. While studies had relied on specific frameworks to explain related behaviour over the years to understand its impact. However, due to some shortfalls of these frameworks, it may not be a complete yardstick to assess Muslim consumer behaviour. The universality of the measurements that were used is assumed to be compatible across different religions and fields of study but has ignored the need to have a compatible measurement. Whereas, its operationalization in the previous studies might not be suitable to assess its impact in the context of consumer research. As such outcome may not adequately reflect nor explain the religiosity factors concerning Muslims. Therefore, this paper is to highlight the need to discuss the challenges and improvement of the measurement to suits the specific contextual settings. This will shed the light in developing an improved religiosity measurement tailored towards Muslim consumers.
\end{abstract}

Keywords: Religiosity, Muslim Religiosity, Muslim Consumers, Muslim Consumer Behaviour.

\section{Introduction}

Recent trends showed shown that the world is developing towards a global renaissance of organized religiosity (Armstrong, 2001; Arnould, Price and Zikhan, 2004). Many works in various fields of studies including in consumer behaviours had included this variable in predicting human behaviour. Religion is an important cultural aspect and social institution that is universal and most significant in influencing attitude, values, and behaviour (Mokhlis, 2006; Rafiki and Abdul Wahab, 2014). Understanding religion and consumers in Muslim consumer market had focused more on religiosity. It has been the key theme used by most researchers lately. 
INTERNATIONAL JOURNAL OF ACADEMIC RESEARCH ECONOMICS AND MANAGEMENT SCIENCES Vol. 10, No. 1, 2021, E-ISSN: 2226-3624 @ 2021 HRMARS

Table 1: Systematic Literature Search on Religiosity

\begin{tabular}{|c|c|c|c|c|c|}
\hline Databases & Google Scholar & WoS & Scopus & EBSCOhost & Proquest \\
\hline \multirow{2}{*}{$\begin{array}{cc}\text { Religiosity } & \text { Feb 2020 } \\
& \text { (Sept 2020) } \\
\end{array}$} & 447000 & 14145 & 12331 & 35109 & 12469 \\
\hline & (499000) & (14193) & (13232) & (44183) & (13166) \\
\hline Islamic Religiosity & 3400 & 115 & 105 & 284 & 135 \\
\hline Muslim Religiosity & 2350 & 62 & 79 & 189 & 62 \\
\hline $\begin{array}{l}\text { Religiosity and consumer } \\
\text { behaviour }\end{array}$ & 6330 & 85 & 100 & 181 & 964 \\
\hline
\end{tabular}

Source: Various Databases (Accessed $7^{\text {th }}$ February 2020 and $27^{\text {th }}$ September 2020)

A systematic literature search conducted using five widely used databases revealed such tremendous attention on religiosity. As of February 2020, there are a total of 521, 054 of research and continued to increase in September 583, 774. This trend indicates that religiosity is gaining momentum in terms of numbers and attention as shown in Table 1. Further examination of the subject revealed that there were works that specifically scrutinized either Islamic Religiosity or Muslim Religiosity. However, it is still relatively small in numbers which within the range of $0.7 \%$ (Google scholar) $1.25 \%$ (WoS), 1.5\% (Scopus), 1.34\% (EBSCOhost) to 1.57\% (Proquest) of the total research that emphasized on religiosity. Religiosity from an Islamic perspective remains limited (Shukor and Jamal, 2013; Newaz, 2014; Mokhlis, 2006).

Moreover, further examination of the contents and context revealed that there are only 741 articles were focused on religiosity and Muslim consumers fit the context of this research. Not to mention, more established and exclusive the database, it scored much lower in numbers due to its stringent quality of publications as shown in figure 1. Nevertheless, the importance of religiosity in advancing the frontier of consumer behaviour is undeniable. Many researchers urged for more research focusing on the subject from an Islamic perspective (Abou Youssef et al., 2011; El-Bassiouny, 2016; Khraim, 2010; Jafari and Sandikci, 2015). 


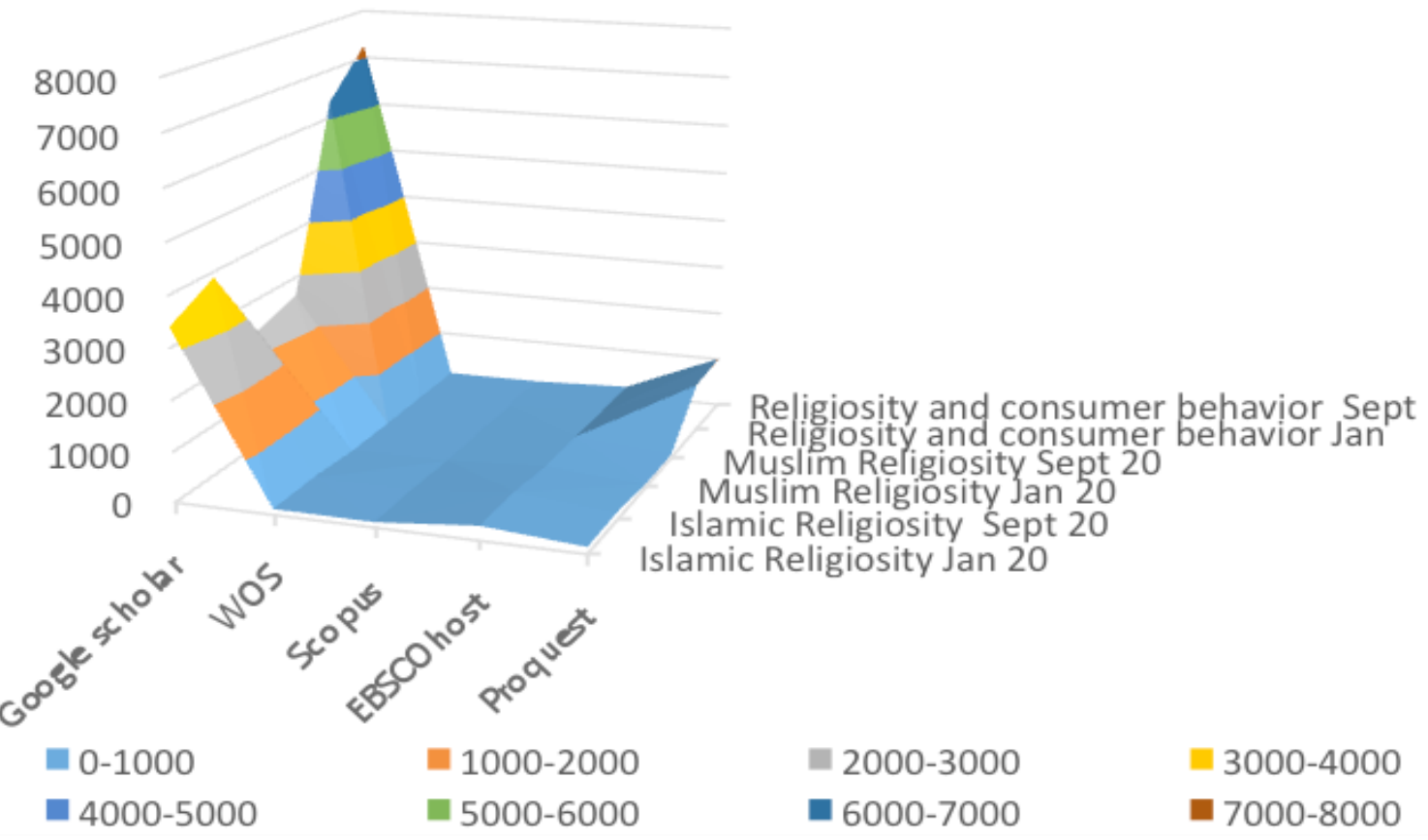

Figure 1: Systematic Literature Search on Islamic Religiosity, Muslim Religiosity and Religiosity and Consumer - February 2020 and September 2020.

While there is some effort to explore Muslim consumer behaviour by incorporating these religiosity measurements and scales. However, its adoption has been limited in the consumer behaviour studies focusing on Muslims, not until recently. Since a vast majority of the study had adopted religiosity measurements or scales based on Judeo-Christian worldview within the context of the western population. Among the popular adoption were taken from Allport and Ross (1967) Worthington et al. (2003), Wilkes et al. (1986), and Stark and Glock (1968) as shown in table 2. Therefore, the adoption of these measurements also leads to the question of how these measurements were operationalized in the research. Suitability of the items and modification as to suits the variable in hands would be crucial to show that Muslim or Islamic religiosity is measured correctly. 
INTERNATIONAL JOURNAL OF ACADEMIC RESEARCH ECONOMICS AND MANAGEMENT SCIENCES Vol. 10, No. 1, 2021, E-ISSN: 2226-3624 @ 2021 HRMARS

Table 2: Adoption of religiosity scales used in consumer research

\begin{tabular}{lll}
\hline Religiosity scale Frequency & $\begin{array}{l}\text { Research that adopts conventional religiosity } \\
\text { measurements* }\end{array}$ \\
\hline
\end{tabular}

Allport and Ross (1967) $12 \quad$ Arli (2017), Ilter, Bayraktaroglu and Ipek (2017), Islam and Chanrasekaran (2016), Abou Youssef, Khartom, Abou-Aish and El Bassiouny (2015), Karami, Olfati and Dubinski (2014), Aydemir and Egilmez (2010), Arli and Tjiptono (2013), Abdur Razzaque and Chaudhry (2013), Uysal and Okumus (2019), Muhamad Hashim and Mizerski (2010), Muhamad, Leong and Mizerksi (2016), Arli and Tjiptono (2018)

Worthington et al. (2003) 9 Mokhlis (2006), Mansori, Sambasivan and Md-Siddin (2015), Bachleda, Hamelin and Benachour (2014), Mukhtar, Mohsin Butt (2012), Kusumawardhini, Hati and Daryanti (2016), Yousaf and Malik (2013), Abdur Razzaque and Chaudhry (2013), Akermi and Smaoui (2016): Iranmanesh, Mirzaei, Hosseini and Zailani (2019);

\begin{tabular}{lll}
\hline Wilkes et al. (1986) & 4 & $\begin{array}{l}\text { Ahmed, Anang, Othman and Sambasivan (2013), Moschis } \\
\text { and Ong (2011), Abdolvand and Azima (2015), Tabassi, } \\
\text { Esmaeilzadeh and Sambasivan (2012); }\end{array}$ \\
\hline Stark and Glock (1968) & 2 & Newaz (2014), Wahyuni (2016)
\end{tabular}

*Based on authors on systematic literature review

Since most of these works did not provide a clear justification of adopting their measurements and scales for their research. A majority had adopted conventional religiosity with little modification even though the sample to a certain extent varies in terms of their religious ideology and practices. This had put greater concern on the suitability of measurements and sample representativeness (Kamil, Zainol, and Ram Jaffri, 2012). For instance, Dekhil, Boulebech, and Bouslama (2017) despite focusing on Tunisian Muslims, had adopted a multi-religious instrument that was tailored for a universal audience (see Worthington et al., 2013; Mokhlis, 2006). Many works had also reported similar adoptions (see Rahayu Hijrah Hati and Idris, 2014; Abdur Razzaque and Chaudhry, 2013) that ignored the importance of providing the rationale for the adoptions both in religion and cultural context (Salam, Muhammad, and Leong, 2019).

Even though numerous religiosity measurements and scales for Muslims are available as opposed to conventional religiosity. It is largely developed in the field of psychology (Albelaikhi, 1997; Abu Raiya, Pargament, Mahoney and Stein, 2008; Khan, 2014) and limitedly adopted that might hamper the effort in understanding Muslim consumer behaviour. Adopting these measurements requires certain operationalisation adjustments to suits consumer research settings (Salam, Muhammad, and Leong, 2019). While, there are adoption of more generic scales of religiosity for Muslims (e.g. Alam et al., 2011; Rehman, and Shabbir, 2010; Abd Rahman, Asrarhaghighi and Ab Rahman, 2015) also shows a limited modification of these measurements. Unlike Usman, Tjiptoherijanto, Baqiah and Agung (2017) most research had maintained the items with limited or no adjustments of the measurement (Alam, Janor, 
Zanariah, CheWel and Ahsan, 2012; and Abd Rahman, Asrarhaghighi and Ab Rahman, 2015). The operationalisation of these measurements or items might not be suitable for this field of study. Thus, indicates that little has been carried out in developing religiosity tailored towards other disciplines, especially in the marketing field (Salam, Muhammad, and Leong, 2019; UlHaq, Butt, Ahmed and Al-Said, 2019).

\section{Literature Review Definition of Religiosity}

Scholars in the field had put forward several definitions, McDaniel and Burnett (1990) defined religiosity as "A belief of God accompanied by a commitment to follow principles believed to have set by God". While, Worthington et al. (2003) defined religiosity as "The degree to which a person uses or adheres to his or her religious values, belief and practices and uses them in daily living". On the other hand, As cited in Manap et al. (2013), Uthman El Muhammady defined religiosity as "the manifestation of committed religious life in an individual, which discerns from the depth of his belief".

\section{Religiosity Measurement for Muslims}

Religion is highly sensitive to Muslims in general, but to a certain extent, this depends on the level of their devotedness or religiosity (Said, Hassan, Musa, and Rahman, 2014). Muslim consumers may vary in their behaviour due to differences of their religiosity level (AbouYoussef, Kortam, Abou-Aish and El-Bassiouny, 2015). Whereas, according to Mokhlis (2006), a religious individual is prone to translate their internal religious belief into external consumer behavioural activities. In the context of consumer behaviour, two main constructs of religion that can be utilized are religious affiliation and religiosity (McDaniel and Burnet, 1990). While Newaz (2014) posited religiosity represents inherent human values that are observable and more practical to marketers. Motivated by the importance of having religiosity impact on behaviour, development of Islamic or Muslim religiosity scale has been flourishing. Of late there have been studies had developed religiosity measurement for Muslims, as shown in Table 3. 
INTERNATIONAL JOURNAL OF ACADEMIC RESEARCH ECONOMICS AND MANAGEMENT SCIENCES Vol. 10, No. 1, 2021, E-ISSN: 2226-3624 @ 2021 HRMARS

Table 3: Religiosity classification and development

\begin{tabular}{lll}
\hline Classification & Total & Developer of Scale (Sources) \\
\hline Islamic Religiosity & 10 & Jana-Masri and Priester (2007), Abu Raiya et al. (2008), \\
& Tiliouine and Belgoumidi (2009), Dali, Yousafzai and Abdul \\
& Hamid (2016), Kamil, Zainol and Ram Al Jaffri (2012), \\
& $\begin{array}{l}\text { Alghorani (2008), Krauss et al. (2007), Salleh (2012), Usman } \\
\text { et al. (2017); Ji and Ibrahim (2007), }\end{array}$ \\
\hline Muslim Religiosity & Albelaikhi (1997), Ul-Haq et al. (2019), El Manouar (2014), \\
& Mahudin, Noor, Dzulkifli and Janon (2016), Olufadi (2016), \\
& Qasmi and Jahangir (2011), Khan (2014), Khraim (2010); \\
& Ihsan Herlina and Chotidjah (2017) \\
\hline Religiosity (Generic) & Awan, Siddiquei and Haider (2015), Abd Rahman, \\
& Asrarhaghighi and Ab Rahman (2015), Alam et al. (2012), \\
& Abdel Khalek (2015), Alam, Mohd and Hisham (2011), \\
& Baazeem (2015), Newaz (2014), Rehman and Shabbir (2010), \\
& Shukor and Jamal (2013) \\
\hline
\end{tabular}

\section{Challenges in Developing Religiosity Measurement for Muslims}

Several had put forward the challenges in developing religiosity measurement for Muslims. One of the challenges is the concern on the content validity of the constructs for Muslim religiosity which are not part of the existing western canon (UI-Haq et al., 2019). Certain individual traits are manifested and reflected in their practices and behaviour. This is in line with Manap et al. (2013) suggested the development of measurement can be measured outwardly. Therefore, this is called not only for theoretical virtue (knowledge) but also practical virtue (good behaviour). As Ul-Haq et al. (2019) argued that spirituality is an integral part of religiosity and it is strongly linked to each other. This is however will be difficult to be measured. While, Manap et al. (2013) acknowledged that it is possible to develop such religiosity but, certain assessments or actual measurements belong to Allah especially one's spirituality.

Other than that, concern over the private and confidential information especially on religious belief and behaviour of the sample would sometimes be misleading and not precise (AbouYoussef et al., 2011). Manipulation to the authors' opinion might happen due to social desirability similarly raised by Albelaikhi (1997). As coined by Ul-Haq et al. (2019) constructs validity is also one of the most difficult challenges in developing religiosity measurement. AbouYoussef et al. (2011) suggested that a questionnaire could be used to describe religion by directly asking the respondents about their religious affiliation or preferences. This type of instrument is using the associational technique used in psychology. However, for this type of questionnaire to be operationalised in consumer research, this paper urged that the development of the items must consider the context of the research being carried out.

Moreover, the rising attention of research focuses on consumption and religiosity called for more sound items and measurements. Items of measuring religiosity must be developed by asking questions on the matter related to the manifestation of religious belief, practices, etc. towards consumption. This kind of associational technique would be better in asking the level of religiosity of Muslims in consumer. Items such as 'I pray five times a day', 'I regularly fast 
during Ramadhan' would affect the respondents to answer it with higher biasness, especially when the questionnaire is distributed and collected via face-to-face interaction.

According to Albelaikhi (1997) measuring belief dimension lead to a lack of variance in the response to some items and had resulted in the loss of many items. This construct applies to all Muslim, since every Muslims is supposed to possess the basic belief as to be Muslim. It would be guaranteed any measurement focusing on the Muslim belief would get zero variation. Thus, modifying the question by using this kind of technique might give a solution to such a construct. Usman et al. (2017) had demonstrated a good development of religiosity adopted from Tiliouine and Belgoumidi (2009). Items were modified with suitable items that measuring the manifestation of one's religious belief in the context of Islamic banking.

Besides, Albelaikhi (1997) had also highlighted on the demographical challenges in developing appropriate items. Issue such as gender differences would affect the development of scale; some items or scales are only applied for men. Sensitivity and offensiveness of the items to measure religiosity must also be highly considered. Development of the items for the measurement must take into consideration social, cultural and religious context to avoid problem (Abou Youssef et al., 2011; El-Bassiouny, 2016; Khraim, 2010). Therefore, to provide item soundness is crucial in tackling on the matter of representativeness, relatedness, the constructs of concern and the domain of interest, clarify of items and understandability. Several works such as Ul-Haq et al. (2019) and Abou-Youssef et al. (2011) as similarly highlighted these issues.

A similar vein, Ul-Haq et al. (2019) called on ensuring the appropriateness of the target respondents by understanding the population for the intended measurements. This is to avoid issues such as cultural inappropriateness and representativeness. Albelaikhi (1997) once highlighted the challenge on the sampling, focusing on the sample characteristics in ensuring heterogeneity or differences between groups of subjects to be compared, concerning the subject of interest to have useful variance. The author also suggests that research obtain a large sample size as possible and a minimum of five subjects for each item to further subject the data to confirmatory factor analyses following exploratory factor analyses. Most of the measurements and scales employed exploratory factor analyses, not to the extent of confirmatory factor analyses.

Furthermore, a carefully developed measurement or scale of religiosity for Muslims must emphasize the items for the construct and carry them out with extreme care. Salam, Muhammad, and Leong, (2019) suggested evaluation criteria based on Abu Raiya and Hill (2014) to assess religiosity constructs. These criteria include theoretical clarity, sample representativeness, reliability, validity, and generalizability. As for consumer research, additional criteria such as clarity of objective and nature of the influence of religion and the length of the questionnaire are also applied. Ul-Haq et al. (2019) also highlighted the issue of determining the total number of dimensions. Numerous dimensions have been suggested, however which dimension is the most salient in which context is an unresolved empirical question. Developing more extensive measurements and scales would requires more dimensions to be explored and validated and more items needed. However, as to fit into consumer research such measurement and scales prone to have very limited items. Therefore, additional criteria as suggested earlier will apply 


\section{Improvement of Instrumentation on religiosity measurement in consumer research}

While some generic religiosity that was adapted and modified from the early works on religiosity for Muslims had looked into its relationship in the context of Muslim consumption such as new product adoption, Halal purchase intention, undertaking Islamic Banking selection (Rehman and Shabbir, 2010; Alam Mohd and Hisham, 2011; Alam et al. 2012; Awan, Siddiquei and Haider, 2015; Abd Rahman, Asrarhaghighi and Ab Rahman, 2015). Even though such research had investigated religiosity and its relationship. However, it was not aimed to develop a new measurement on religiosity for Muslims. Since these works have been adapted from various sources, therefore religiosity items had been limited to suits into their research context. It might not be able to reflect the true conceptualization of religiosity for Muslims and its relationship to their behaviour (Abou Youssef et al., 2011; El-Bassiouny, 2016; Khraim, 2010; Shukor and Jamal, 2013).

As most of the Muslim or Islamic religiosity constructs were focused on beliefs and practices that are more in religious practices. These are the two of the most important constructs in religiosity measurements. Apart from that, there is a need to focus on other religiosity constructs to better find out its relationship towards consumer behaviour. Several constructs can be further investigated in understanding Muslim consumer religiosity impacting muammalat or specifically marketing-related activities (UI-Haq et al., 2019; Dali et al., 2019). In this case, the religiosity concept should be extended and to measure the commitment beyond just belief and practices within the Islamic framework. In the consumer research context, there is a need to incorporate important aspects relevant to religiosity that had emerged in the literature. Previous studies had consistently reported the link of religiosity to several aspects of Muslim consumption.

In the case of religious influence on Muslim consumption practices, it is repeatedly found that religiosity as an antecedent of consumers' intention in Muslims consumption such as in Halal cosmetics, Halal food products and certain had focused on moderating effects between Halal brand and purchase intention (Abd Rahman, Asrarhaghigi and Ab Rahman, 2015; Awan, Siddiquei and Haider, 2015; Said, Hassan, Musa and Rahman, 2013: Mukhtar and Mohsin Butt, 2012; Asnawi, Sukoco and Fanani, 2018; Borzooei and Asgari, 2013; 2014). While in Banking and finance, religiosity was found to have a significant relationship toward Islamic home financing, moderates the impact on Islamic financial purchase, affects the brand aura and loyalty in Islamic banking, influenced purchase intention Islamic banking products, and impacting on consumer attitude towards Islamic banking (Alam et al., 2012; Newaz, 2014; Wahyuni, 2016; Wahyuni and Fitriani, 2017; Souiden and Rani, 2015; Abou-Youssef et al., 2015; Khraim, 2010).

Other than that, religiosity is closely related to values that affect the ethical behavioural intention of Muslim consumers. While being as antecedents of attitude towards ethical consumer behaviour and affecting ethical behaviour of Muslims. Religiosity was also found to be significant in affecting ethical belief, ethical awareness, ethical behaviour, and ethical judgments and boycotting (Vitell, Paolillo, and Singh, 2005; Muhamad, 2009; Aydemir and Egilmez, 2010; Walker, Smither and Debode, 2012; Uysal and Okumus, 2019) both among Muslims and also non-Muslims. While, according to Parboteeah, Hoegel, and Cullen (2007) cognitive, affective and behaviour dimensions of religiosity affect ethics in certain ways. Arli and Tjiptono (2013) similarly found this religiousness affects ethics apart from materialism and 
long-term orientation. This is evidence that ethics or values are an inseparable aspect of religiosity.

Others had found the link between religiosity and knowledge (Maison et al., 2018; Muhamad Hashim and Mizerski, 2010; Muhamad, Leong and Mizerski, 2016; Usman et al., 2017; Abdur Razzaque and Chaudhry, 2013). These works focused on exploring the effects of religiosity and knowledge in determining intentions, involvement, and choosing a foreign product based on COO. Religiosity influence on the effort of searching for valid and reliable information such as fatwa ruling (Muhamad Hashim and Mizerski, 2010). That is determined by their religious orientation eventually differentiates knowledge on fatwa ruling (Muhamad, Leong, and Mizerski, 2016). While current religiosity measurements had specific dimensions on this aspect and in research related to religiosity and Halal food products

Previous studies also reported that the environment is part of religiosity for Muslims. This construct was highlighted by Krauss et al. (2007) but however not comprehensively developed. Research had found that religiosity acted as an antecedent of behaviour in predicting green purchase intention (Khan and Kirmani, 2018), several studies found moderating effects of religiosity, it moderates the impact of environmental factors in Pro-Environmental Consumer Behavior (PECB) and environmental orientation and practices (Bhuian, Sharma, Butt and Ahmed, 2018; Hari Adi and Adawiyah, 2018). According to Akermi and Smaoui (2016), religiosity can be considered as a predictor of Socially Responsible consumption (based on Kabasakal and Bodur, 2002). However, the operationalisation of this construct has not been emphasized in religiosity measurement development.

Besides that, Muslim religiosity is reported to effects socially responsible consumption in addressing issues such as poverty and charity, CSR, and environmental concerns (Lau and Tan, 2009; Lau, 2010). It is also reported that respondents with high religiosity particularly in pay attention to firms' behaviour, buying cause-related products leads to a greater tendency to buy from small businesses (Anuar, Adam and Omar, 2012; Akermi and Smaoui, 2016). While Graafland (2017) found religiosity affects pro-social behaviour but not extending to buying SR products. However, religiosity measurement for Muslims has not been focused on developing this construct. Even though, works had however proposed their dimensions that relate to social responsibility. This is crucial since it will determine differences in brands and behaviour on selected products. All the constructs such as belief, practices, values, knowledge, environmental responsiveness, and social responsiveness require further investigation to better understand specific factors of Muslim consumer religiosity

\section{Conclusion and Recommendation}

There is a need to develop a new improved religiosity measurement that focuses on consumer research. Since contextual settings and operationalisation of this measurement must tailor towards consumer research. The raising attention of looking its impact on a consumer-related variable called for more suitable religiosity measurement (Salam, Muhammad, and Leong, 2019; Ul-Haq et al., 2019; Dali et al., 2019). As suggested by Shukor and Jamal (2013) urged to develop religiosity measurement that is to suit consumer research. The author had argued based on Khraim (2010) that the developed religiosity scale more on practical behaviour might not be able to capture the true meaning of Islam. Islam according to the author is not mere belief but a complete way of life. Thus, a religiosity scale needs to be further developed in order to provide 
wider religiosity measurement. This paper shares a common view, which called for more specific religiosity measurement, tailored towards specific components of human behaviour. It is expected that more instruments can be developed in measuring specific components of religiosity and Muslim personality for the purpose of assessment, development, and empowerment of individual and Muslim community (Manap et al., 2013). Therefore, specific religiosity components looking into consumer perceived religiosity on consumption might provide better constructs understanding Muslim consumer behaviour.

The conceptualisation of more comprehensive constructs focusing perceived religiosity on consumption and behaviour of Muslim consumers will help the marketers and practitioners. This will enable them to develop segmentation and strategy in understanding customer intention and preferences in offering their product and services. Since religiosity is an important part of consumer behaviour that is gaining momentum and attention however still poorly understood both by marketers and business practitioners. It is suggested that the conceptualisation of religiosity in consumer research can be expanded on several aspects such as belief, practices, values, knowledge, environmental responsiveness and social responsiveness as shown in figure 2.

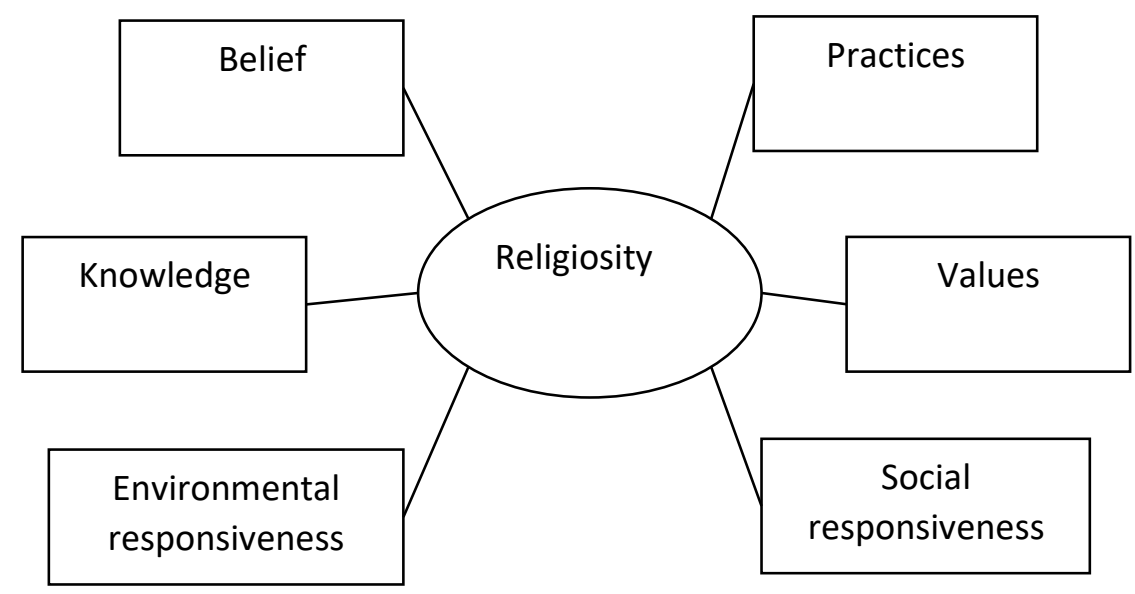

Figure 2: Muslims consumer religiosity constructs

\section{References}

Abd Rahman, A., Asrarhaghighi, E., \& Ab Rahman, S. (2015). Consumers and Halal cosmetic products: knowledge, religiosity, attitude and intention. Journal of Islamic Marketing, 6(1), 148-163.

Abdolvand, M. A., \& Azima, S. (2015). The role of ethnocentrism, religiosity, animosity, and country-of-origin image, in foreign product purchase intention case study: buying saudi products by iranian consumers. International Journal of Marketing \& Financial Management, 3(11), 71-93.

Abdur Razzaque, M., \& Chaudhry, N. S. (2013). Religiosity and Muslim consumers' decisionmaking process in a non-Muslim society. Journal of Islamic marketing , 4(2), 198-217. 
Abou-Youssef, M., Kortam, W., Abou-Aish, E., \& El-Bassiouny, N. (2011). Measuring Islamic-driven buyer behavioral implications: a proposed market-minded religiosity scale. Journal of American Science, 7(8), 728-741.

Abou-Youssef, M. M. H., Kortam, W., Abou-Aish, E., \& El-Bassiouny, N. (2015), "Effects of religiosity on consumer attitudes toward Islamic banking in Egypt", International Journal of Bank Marketing, 33(6), 786-807.

Abu Raiya, H., Pargament, K. I., Mahoney, A., \& Stein, C. (2008). A psychological measure of Islamic religiousness: Development and evidence for reliability and validity. The International Journal for the Psychology of Religion, 18(4), 291-315.

Abu-Raiya, H., \& Hill, P. C. (2014), "Appraising the state of measurement of islamic religiousness", Psychology ofReligion and Spirituality, 6(1), 22-32.

Hari Adi, P., \& Adawiyah, W. R. (2018). The impact of religiosity, environmental marketing orientation and practices on performance. Journal of Islamic Marketing. 9(4), 841-862.

Ahmed, Z., Anang, R., Othman, N., \& Sambasivan, M. (2013). To purchase or not to purchase US products: role of religiosity, animosity, and ethno-centrism among Malaysian consumers. Journal of Services Marketing. 27 (7), 551-563.

Khalek, A. (2015), Determinants influencing Halal food consumption among generation $Y$ Muslims in Malaysian private universities. Unpublished Doctorate Thesis, University of Malaya.

Akermi, A., \& Smaoui, F. (2016). the effect of cultural values and religiosity on socially responsible consumption. Proceedings of the Marketing Spring Colloquy, 6, 22.

Alam, S. S., Mohd, R., \& Hisham, B. (2011). Is religiosity an important determinant on Muslim consumer behaviour in Malaysia? Journal of Islamic Marketing, 2(1), 83.

Alam, S. S., Janor, H., Zanariah, C. A. C. W., \& Ahsan, M. N. (2012). Is religiosity an important factor in influencing the intention to undertake Islamic home financing in Klang Valley. World Applied Sciences Journal, 19(7), 1030-1041.

Albelaikhi, A. A. (1997). Development of a Muslim Religiosity Scale. Unpublished PhD thesis, University of Rhode Island

Alghorani, M. A. (2008). Knowledge-Practice Measure of Islamic Religiosity (KPMIR): A case of high school Muslim students in the United States. Journal of Muslim Mental Health, 3(1), 25-36.

Allport, G. W., \& Ross, J. M. (1967). Personal Pre-Publication Draft 7 religious orientation and prejudice. Journal of Personality and Social Psychology, 5, 432-443.

Anuar, M. M., Adam, F., \& Omar, K. (2012). The role of religiosity in socially responsible consumption. International Journal of Asian Social Science, 2(9), 1467-1476.

Arli, D. (2017). Does ethics need religion? Evaluating the importance of religiosity in consumer ethics. Marketing Intelligence \& Planning, 35(2), 205-221.

Arli, D. I., \& Tjiptono, F. (2018). Consumer ethics, religiosity, and consumer social responsibility: are they related?. Social Responsibility Journal, 4(2), 302-3320.

Arli, D., \& Tjiptono, F. (2013). The end of religion? Examining the role of religiousness, materialism, and long-term orientation on consumer ethics in Indonesia. Journal of Business Ethics, 123(3), 385-400.

Armstrong, K. (2011). The battle for God: A history of fundamentalism. Ballantine Books.

Arnould, E., Price, L. \& Zikhan, G. (2004), Consumers, 2nd ed., McGraw-Hill, New York, NY. 
Asnawi, N., Sukoco, B. M., \& Fanani, M. A. (2018). Halal products consumption in international chain restaurants among global Moslem consumers. International Journal of Emerging Markets. 13(5), 1273-1290.

Aydemir, M., \& Egilmez, O. (2010). The relationship between the religiosity and the ethical attitudes of managers: An empirical study. $2^{\text {nd }}$ International Symposium on Sustainable Development, June 2010, 247-253.

Baazeem, T. A. S. (2015). How religiosity influences consumption: The impact of consumer religiosity on perceptions of psychological and social risk (Doctoral dissertation, Queensland University of Technology).

Bachleda, C., Hamelin, N., \& Benachour, O. (2014). Does religiosity impact Moroccan Muslim women's clothing choice? Journal of Islamic Marketing, 5(2), 210-226.

Bhuian, S. N., Sharma, S. K., Butt, I., \& Ahmed, Z. U. (2018). Antecedents and pro-environmental consumer behavior (PECB): The moderating role of religiosity. Journal of Consumer Marketing. 25(3) 287-299.

Borzooei, M., \& Asgari, M. (2013). The Halal brand personality and its effect on purchase intention. Interdisciplinary Journal of Contemporary Research in Business, 5(3), 481-491.

Borzooei, M., \& Asgari, M. (2014). The effect of religious commitment on halal brand relationship and purchase intention. The International Journal's Research Journal of Economics and Business Studies, 3(4), 14-19.

Dali, N. R. S. M., Yousafzai, S., \& Hamid, H. A. (2019). Religiosity scale development. Journal of Islamic Marketing. 10(1), 227-248.

Dekhil, F., Boulebech, H., \& Bouslama, N. (2017). Effect of religiosity on luxury consumer behavior: the case of the Tunisian Muslim. Journal of Islamic Marketing, 8(1), 74-94.

El-Bassiouny, N. (2016). Where is "Islamic marketing" heading? A commentary on Jafari and Sandikci's (2015) "Islamic" consumers, markets, and marketing. Journal of Business Research, 69(2), 569- 578.

El-Menouar, Y. (2014). The five dimensions of Muslim religiosity. Results of an empirical study. methods, data, analyses, 8(1), 26.

Graafland, J. (2017). Religiosity, attitude, and the demand for socially responsible products. Journal of Business Ethics, 144(1), 121-138.

Awan, H. M., Siddiquei, A. N., Haider, Z. (2015) "Factors affecting Halal purchase intention evidence from Pakistan's Halal food sector", Management Research Review, 38(6), 640-660

Ihsan, H., Herlina, M., \& Chotidjah, S. (2016). The Validation of Skala Ritual Religious Harian Muslim (Daily Moslem Religious Rituals Scale). In 1st International Conference on Social and Political Development (ICOSOP 2016). Atlantis Press.

Ilter, B., Bayraktaroglu, G., \& Ipek, I. (2017). Impact of Islamic religiosity on materialistic values in Turkey. Journal of Islamic Marketing, 8(4), 533-557.

Iranmanesh, M., Mirzaei, M., Hosseini, P. S. M., \& Zailani, S. (2020), "Muslims' willingness to pay for certified Halal food: an extension of the theory of planned behavior", Journal of Islamic Marketing, 11(1), 14-30.

Islam, T., \& Chandrasekaran, U. (2016). Effect of religiosity on ecologically conscious consumption behaviour. Journal of Islamic Marketing, 7(4), 495-507. 
Jafari, A., \& Sandıkcı, Ö. (2015). Islamic'consumers, markets, and marketing: A critique of ElBassiouny's (2014)“The one-billion-plus marginalization. Journal of Business Research, 68(12), 2676-2682.

Jana-Masri, A., \& Priester, P. E. (2007). The development and validation of a Qur'an-based instrument to assess Islamic religiosity: The religiosity of Islam scale. Journal of Muslim Mental Health, 2(2), 177-188.

Ji, C. H. C., \& Ibrahim, Y. (2007). Islamic doctrinal orthodoxy and religious orientations: Scale development and validation. The international journal for the psychology of religion, 17(3), 189-208.

Kabasakal, H., \& Bodur, M. (2002), "Arabic cluster: a bridge between East and West", Journal of World Business, 37(1), 40-54.

Kamil, M. I., Zainol, B., \& Ram Al Jaffri, S. (2012). Islamic religiosity measurement and its relationship with business income zakat compliance behavior. Jurnal Pengurusan, 34, 3-10.

Karami, M., Olfati, O., \& Dubinsky, a J. (2014). Influence of religiosity on retail salespeople"s ethical perceptions: The case in Iran. Journal of Islamic Marketing, 5(1), 144-172

Khan, M. J. (2014). Construction of Muslim religiosity scale. Islamic Studies, 67-81.

Khan, M. N., \& Kirmani, M. D. (2018), "Role of religiosity in purchase of green products by Muslim students: Empirical evidences from India", Journal of Islamic Marketing, 9 (3), 504-526.

Khraim, H. (2010). Measuring religiosity in consumer research from Islamic perspective. International Journal of Marketing Studies, 2(2), 166.

Krauss, S. E., Hamzah, A., \& Idris, F. (2007). Adaptation of a Muslim religiosity scale for use with four different faith communities in Malaysia. Review of religious research, 147-164.

Lau, T. C. (2010). Towards socially responsible consumption: an evaluation of religiosity and money ethics. International Journal of Trade, Economics and Finance, 1(1), 32.

Lau, T. C., \& Tan, B. C. (2009). Religiosity as antecedent of attitude towards green products: An exploratory research on young Malaysian consumers. Asean Marketing Journal, 1(1): 3341.

Kusumawardhini, S. S., Rahayu, S., Hati, H., \& Daryanti, S. (2016). Understanding Islamic Brand Purchase Intention: The Effects of Religiosity, Value Consciousness, and Product Involvement. In BE-ci 2016 : 3rd International Conference on Business and Economics, 154166.

Maison, D., Marchlewska, M., Syarifah, D., Zein, R. A., \& Purba, H. P. (2018). Explicit versus implicit "halal" information: Influence of the halal label and the country-of-origin information on product perceptions in Indonesia. Frontiers in psychology, 9, 382.

Manap, J. H., Hamzah, A., Noah, S. M., Kasan, H., Krauss, S. E., Mastor, K. A., \& Idris, F. (2013). Prinsip Pengukuran Religiositi Dan Personaliti Muslim. Jurnal Psikologi dan Pembangunan Manusia, 1(1), 36-43.

Mansori, S., Sambasivan, M., \& Md-Sidin, S. (2015). Acceptance of novel products: the role of religiosity, ethnicity and values. Marketing Intelligence \& Planning, 33(1), 39-66.

McDaniel, S. W., \& Burnett, J. J. (1990). Consumer religiosity and retail store evaluative criteria. Journal of the Academy of marketing Science, 18(2), 101-112.

Mahudin, M. N. D., Noor, N. M., Dzulkifli, M. A., \& Janon, N. S. (2016). Religiosity among Muslims: A scale development and validation study. Makara Hubs-Asia, 20(2), 109-121. 
Mokhlis, S. (2006). The influence of religion on retail patronage behavior in Malaysia, Phd Thesis, Universiti of Sterling, 190-308.

Moschis, G. P., \& Ong, F. S. (2011). Religiosity and consumer behavior of older adults: A study of subcultural influences in Malaysia. Journal of Consumer Behaviour, 10(1), 8-17.

Hashim, M. N., \& Mizerski, D. (2010). Exploring Muslim consumers' information sources for fatwa rulings on products and behaviors. Journal of Islamic Marketing, 1(1), 37-50.

Muhamad, N., Leong, V. S., \& Mizerski, D. (2016). Consumer knowledge and religious rulings on products. Journal of Islamic Marketing. 7(1), 74-94.

Muhamad, R. (2009). Religiosity, ethical judgments and Malaysian Muslim students. Journal of Law and Governance, 4(1).

Mukhtar, A., \& Butt, M. (2012). Intention to choose Halal products: the role of religiosity. Journal of Islamic Marketing, 3(2), 108-120.

Newaz, F. T. (2014). Religiosity, Generational Cohort and Buying Behaviour of Islamic Financial Products in Bangladesh. Wellington: Victoria University of Wellington.

Olufadi, Y. (2017). Muslim Daily Religiosity Assessment Scale (MUDRAS): A new instrument for Muslim religiosity research and practice. Psychology of Religion and Spirituality, 9(2), 165.

Parboteeah, K. P., Hoegl, M., \& Cullen, J. B. (2008). Ethics and religion: An empirical test of a multidimensional model. Journal of business ethics, 80(2), 387-398.

Qasmi, F. N., \& Jahangir, F. (2010). Development and Validation of a Multidimensional Religiosity Scale for Muslims. FWU Journal of Social Sciences, 4(2).

Rafiki, A., \& Wahab, K. A. (2014). Islamic values and principles in the organization: A review of literature. Asian Social Science, 10(9), 1.

Hati, R. H. S., \& Idris, A. (2014). Antecedents of customers' intention to support Islamic social enterprises in Indonesia: the role of socioeconomic status, religiosity, and organisational credibility. Asia Pacific Journal of Marketing and Logistics, 26(5), 707-737.

Said, M., Hassan, F., Musa, R., \& Rahman, N. A. (2014). Assessing consumers' perception, knowledge and religiosity on Malaysia's halal food products. Procedia-Social and Behavioral Sciences, 130, 120-128.

Salam, M. T., Muhamad, N., \& Leong, V. S. (2019). Measuring religiosity among Muslim consumers: observations and recommendations. Journal of Islamic Marketing. 10(2), 633652.

Salleh, M. S. (2012). Religiosity in development: A theoretical construct of an Islamic-based development. International Journal of Humanities and Social Science, 2(14), 266-274.

Rehman A.-U, \& Shabbir, M. S. (2010). The relationship between religiosity and new product adoption. Journal of Islamic Marketing. 1(1) 63-69.

Shukor, S. A., \& Jamal, A. (2013). Developing scales for measuring religiosity in the context of consumer research. Middle-East Journal of Scientific Research, 13(1), 69-74.

Souiden, N. \& Rani, M. (2015), "Consumer attitudes and purchase intentions toward Islamic banks: the influence of religiosity", International Journal of Bank Marketing, 33(2) 143-161.

Stark, R., \& Glock, C. Y. (1968). American piety: The nature of religious commitment (Vol. 1). Univ of California Press.

Tabassi, S., Esmaeilzadeh, P., \& Sambasivan, M. (2012). The role of animosity, religiosity and ethnocentrism on consumer purchase intention: A study in Malaysia toward European brands. African Journal of Business Management, 6(23), 6890-6902. 
Tiliouine, H., \& Belgoumidi, A. (2009). An exploratory study of religiosity, meaning in life and subjective wellbeing in Muslim students from Algeria. Applied Research in Quality of Life, 4(1), 109-127.

Ul-Haq, S., Butt, I., Ahmed, Z., \& Al-Said, F. T. (2019). Scale of religiosity for Muslims: an exploratory study. Journal of Islamic Marketing, 11(6), 1201 -1224.

Usman, H., Tjiptoherijanto, P., Balqiah, T.E. \& Agung, I.G.N. (2017), "The role of religious norms, trust, importance of attributes, and information sources in the relationship between religiosity and selection of the Islamic bank", Journal of Islamic Marketing, 8(2), 158-186.

Uysal, A., \& Okumus, A. (2019). Impact of Religiosity on ethical judgement: a study preference of retail stores among consumers. Journal of Islamic Marketing, 10(4): 1332-1350.

Vitell, S. J., Paolillo, J. G., \& Singh, J. J. (2005). Religiosity and consumer ethics. Journal of business ethics, 57(2), 175-181.

Wahyuni (2016). Brand Religiosity Aura of Sharia Banking. International Business Management. 10(15), 2732-2741.

Wahyuni, S. \& Fitriani, N. (2017). Brand Religiosity Aura and Brand Loyalty in Indonesia Islamic Banking. Journal of Islamic Marketing, 8(3): 361-372.

Walker, A. G., Smither, J. W., \& DeBode, J. (2012). The effects of religiosity on ethical judgments. Journal of business ethics, 106(4), 437-452.

Wilkes, R. E., Burnett, J. J., \& Howell, R. D. (1986). On the meaning and measurement of religiosity in consumer research. Journal of the Academy of Marketing Science, 14(1), 47-56.

Worthington Jr, E. L., Wade, N. G., Hight, T. L., Ripley, J. S., McCullough, M. E., Berry, J. W., \& O'Connor, L. (2003). The Religious Commitment Inventory--10: Development, refinement, and validation of a brief scale for research and counseling. Journal of counselling psychology, 50(1), 84.

Yousaf, S., \& Malik, M. S. (2013). Evaluating the influences of religiosity and product involvement level on the consumers. Journal of Islamic Marketing, 4(2), 163-186. 